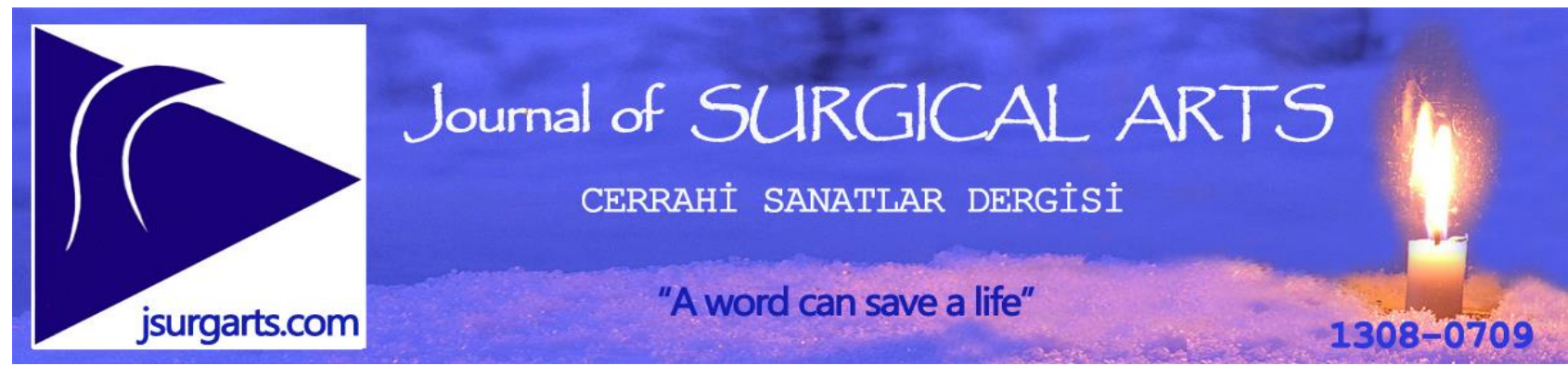

Clinical Practice Study

\title{
Treatment of sepsis secondary to blast injuries
}

\section{Patlama yaralanmalarına sekonder gelişen sepsis tedavisi}

\author{
Mehmet Akdemir'1, Çă̆daş Biçen², Ahmet Ekin² \\ İzmir Ekol Hospital, Department of Orthopedics and Traumatology ${ }^{1}$, İzmir \\ İzmir University of Economics, Medicalpark Hospital, Department of Orthopedics and Traumatology ${ }^{2}$ \\ İzmir, Turkey
}

Address: Dr. Çağdaş Biçen (https://orcid.org/0000-0002-0711-9376), cagdasbicen@ hotmail.com

How to cite: Akdemir M, Biçen Ç, Ekin A. Treatment of sepsis secondary to blast injuries. J Surg Arts: 2021;14(1): 31-40 DOI: https://doi.org/10.14717/jsurgarts-210106

Received: 01.12.2020 Accepted: 30.30.2020

\section{ABSTRACT}

Blast injuries are an important cause of morbidity and mortality due to ongoing conflicts, especially among young patients. Due to the adversities of warfare, the first interventions for these patients are performed in unsuitable environments. Patients generally do not receive further treatment in their own country, but in other countries as wounded war refugees. Local and systemic infections in patients with associated polytrauma, soft tissue damage, and blast effects cause mortality and morbidity.

All of the patients were injured during the Libyan civil war and the first intervention was performed in hospitals in their own country or in Tunisia. The patients were transferred to our clinic by ambulance plane. All patients presented bone-soft tissue infection and sepsis. Bone-soft tissue and blood cultures were obtained from the patients. The first interventions for the patients were performed multidisciplinarily in orthopedics, general surgery, infection, and intensive care clinics. The patients were followed in our clinic for one year including intensive care, service, and outpatient monitoring.

Sixteen patients with a mean age of 28.8 years were included in the study. All patients were wounded by explosives or missiles. The patients were admitted to our clinic at a mean of approximately 24.4 days after these events. The patients were followed in the intensive care unit for an average of 7.9 days. The mean followup was 4 months. After the service follow-up, each patient continued outpatient follow-up for a total of 12 months. Antibiotics were given according to the causative infectious agent during the intensive care and service follow-up. Three patients had lung infections. Colistin-induced renal failure or hepatotoxicity developed due to resistant infections in 4 patients. After colistin was ceased, this situation resolved. Two of the 16 patients died. The sepsis and bone-soft tissue infections were controlled in all other patients. Four patients had femoral nonunion and one patient had short femoral healing. While 2 patients were able to walk without support and 11 patients could walk using support and one patient who was Quadriplegic was unable to walk.

The treatment of bone-soft tissue infections accompanied by sepsis should be multidisciplinary. This should be kept in mind for patients with systemic injuries due to explosion effects. The infectious agents in these patients are often drug-resistant and there may be complications secondary to the antibiotics used during treatment.

Keywords: Libyan civil war; polytrauma; blast injury; sepsis.

\section{ÖZET}

Blast yaralanmaları, devam eden savaşlar nedeniyle özellikle genç hastalarda önemli bir morbidite ve mortalite nedenidir. Savaşın getirdiği olumsuzluklar nedeniyle bu hastalara ilk müdahaleler uygun olmayan ortamlarda yapılmaktadır. Hastalar genellikle kendi ülkelerinde değil, diğer ülkelerde yaralı savaş mültecileri olarak tedavi görürler. Politravma, yumuşak doku hasarı ve blast yaralanmaları olan hastalarda lokal ve sistemik enfeksiyonlar mortalite ve morbiditeye neden olur. 
Hastaların tamamı Libya iç savaşı sırasında yaralanmış ve ilk müdahaleleri kendi ülkelerindeki veya Tunus'taki hastanelerde yapılmıştır. Hastalar ambulans uçak ile kliniğimize sevk edilmişti. Tüm hastalarda kemik-yumuşak doku enfeksiyonu ve sepsis kliniği mevcuttu. Hastalardan kemik, yumuşak doku ve kan kültürleri alındı. Hastalara ilk müdahaleler multidisipliner olarak ortopedi, genel cerrahi, enfeksiyon ve yoğun bakım kliniklerince yapıldı. Hastalar bir yıl süreyle yoğun bakım, servis ve poliklinik takibi dahil olmak üzere kliniğimizde takip edildi.

Çalışmaya yaş ortalaması 28,8 olan 16 hasta dahil edildi. Tüm hastalar patlayıcılar veya füzelerle yaralanmıştı. Hastalar yaralanmalardan ortalama 24.4 gün sonra kliniğimize başvurdu. Hastalar ortalama 7,9 gün yoğun bakımda takip edildi. Ortalama takip süresi 4 aydı. Servis takibinin ardından her hasta toplam 12 ay boyunca ayaktan takibe devam etti. Yoğun bakım ve servis takibinde enfeksiyon etkenine göre antibiyotik verildi. Üç hastada akciğer enfeksiyonu vardı. Dirençli enfeksiyonlara bağlı olarak 4 hastada kolistin kaynaklı böbrek yetmezliği veya hepatotoksisite gelişti. Kolistin kesildikten sonra bu durum düzeldi. 16 hastadan ikisi ex oldu. Diğer tüm hastalarda sepsis ve kemik-yumuşak doku enfeksiyonları kontrol altına alındı. Dört hastada femoral kaynamama ve bir hastada femurda kısalıkla iyileşme görüldü. 2 hasta desteksiz mobilize olabildi, 11 hasta destekle mobilize olabilirken, 1 hasta kuadriplejik kald1.

Sepsisin eşlik ettiği kemik-yumuşak doku enfeksiyonlarının tedavisi multidisipliner olmalıdır. Bu hastalardaki enfeksiyöz ajanlar genellikle antibiyotiklere dirençlidir ve tedavi sırasında kullanılan antibiyotiklere ikincil komplikasyonlar gelişebilir.

Anahtar kelimeler: Libya iç savaşı; politravma; patlama yaralanması; sepsis.

\section{INTRODUCTION}

Blast injuries due to ongoing wars in various parts of the world are important causes of morbidity and mortality, especially among young patients (1). In the treatment of these patients, the first intervention in the field, appropriate transfer of the patient, correction of the general condition of the patient, and proper treatment of limb injuries are vital (2-4). However, due to war conditions, these interventions usually cannot be performed in a timely manner, or they are done inappropriately (5). Patients had mostly heavy injuries during. Especially in cases of missile injuries, polytrauma develops in patients due to the blast effect and the spreading of shrapnel $(6,7)$. When open wounds are subsequently infected, the condition becomes more complex and should be treated by a multidisciplinary team. Patients' first interventions may be performed far from the site of injury due to ongoing warfare and conflict conditions, and patients are often transferred to other countries in various ways $(8,9)$. This results in late, unfavorable, and inadequate initial interventions. As a result, chronic soft tissue and bone infections and nosocomial resistant bacterial infections can lead to sepsis, multiorgan failure, and death in these patients (10).

The importance of the immune system in the development of sepsis in patients with polytrauma has been better understood in recent years. This factor plays a major role in the development of acute respiratory distress syndrome in patients. The existence of both sepsis and acute respiratory distress syndrome in the same case complicates the condition of the patient and makes treatment difficult $(10,11)$.

In this study, we discussed the treatment results of patients who were injured during the Libyan civil war, whose first interventions were performed in Libyan and Tunisian hospitals and who were then transferred to our country by air due to polytrauma, sepsis or multiple organ failure.

\section{MATERIAL and METHOD}

16 patients treated between January.2012August.2020 in our clinic were included in the study. The patients were injured during the Libyan civil war. After a general evaluation, patients with sepsis accompanying musculoskeletal infections were included in the study. Patients who had isolated osteomyelitis or soft tissue infection without systemic sepsis were excluded from the study. Data of the patients were collected using medical records of our hospital and patient folders. Age, time till admission to our hospital from the injury (days), location and mechanism of injuries, labarotary values, physical examination and daily follow notes, operations that we performed, duration of treatment in intensive care unit (days), growths in cultures and duration of follow were recorded.

The first interventions for the patients took place on the battlefield and in hospitals in Libya and Tunisia. The patients were transferred to our clinic by plane ambulance. Diagnosis of sepsis was made according to the following criteria: fever of $>38.5{ }^{\circ} \mathrm{C}$, tachycardia, high mean respiratory rate, and high leukocyte count. The presence of 2 or more of these was accepted as sepsis. Blood cultures were also evaluated at the first admission of the patient. Patients with thoracic, abdominal, or head trauma in addition to large bone fractures were evaluated as patients with polytrauma.

After admission to our clinic, systemic examinations were performed and general statuses were stabilized. All the patients were evaluated by internal medicine, infection, chest disease, orthopedics, general surgery, and plastic surgery teams. Patients with critical vital statuses were taken into intensive care unit. In the intensive care unit, fluid replacement, blood transfusion, close monitoring of vital signs (fever, respiration, pulse, blood pressure, heart 
rhythm, saturation), intravenous broad-spectrum empirical antibiotic therapy, respiratory and nutritional support were given. At the first admission, cultures were taken from open wounds and blood. Antibiotherapies were planned according to culture results. Bone and soft tissue debridement was performed for orthopedic infections in patients whose general conditions improved. Reconstructive operations were performed after the general conditions of the patients improved and they were accepted to clinics from the intensive care unit.

Deep tissue cultures and bone pathologies were evaluated during surgical debridement. In the case of systemic infection, bronchial lavage and open cavities were also cultured. As a result of culturing, bacteria with resistance to 3 or more antibiotics were evaluated as multidrug-resistant bacteria.

Limb reconstructions were performed according to damage-control surgical procedures. Open wounds and infected bone fragments were debrided and open wounds that we were able to close were primarily treated with vacuum-assisted closure (VAC). Open/infected bone fractures were first treated by external fixation. After the general condition of the patients improved, infections were controlled locally and systemically, and internal fixations were performed. Patients with recurrent infection after internal fixation were treated with external fixation.

\section{RESULTS}

Sixteen patients with a mean age of 28.8 years (range: 19-37) were included in the study. All of the patients were male. Nine of the patients was wounded with explosives and 7 with missiles (Table 1). The patients were referred to our clinic at an average of 24.4 days after these events.
Nine of the patients had positive blood cultures. In 2 patients' culture, growth was not observed, but sepsis was diagnosed clinically. Blood cultures were positive for Acinetobacter baumannii in 3 patients, Klebsiella pneumonia in 2 patients, Pseudomonas Aeruginosa in 2 patiens, Escherichia Coli in 1 patient and Enterobacter cloacae in 1 patient. Patients had also growth in bone-soft tissue cultures. The most common bacterium was Acinetobacter baumannii with isolation in 7 cultures. The others were Klebsiella in 6 cultures, Escherichia coli in 4 cultures, Stenotrophomonas in 2 cultures, Enterococcus faecalis in 2 cultures, Providencia stuartii and Enterobacter cloacae in one culture each. In one patient, methicillin-resistant coagulase-negative Streptococcus growth was seen in a late-period culture. The majority of patients had multidrug-resistant gram-negative bacteria (Table 2).

The patients remained in the intensive care unit for an average of 7,9 days (range: 5-20). Patients were admitted to clinics after the clinical and laboratory parameters of sepsis improved in the intensive care unit. Intravenous antibiotics were continued during hospitalization. The patients were discharged when their infection parameters had improved and open wounds had closed. The mean duration of follow-up was 4 months (range: 0.5-10).

All patients had open injuries (Figure 1). Nine patients had femur fractures 3 patients had tibia, 2 patients had vertebra, 2 patients had foot fractures, 1 patient had ulna fracture and 1 patient had scapula fracture. 2 of the patients had additional closed large bone fractures (tibia and femur). These fractures were thought to be associated with shock waves, as these patients were injured by missiles (Figure 2). Five patients had extensive skin defects. These five patients were treated with VAC.

Table 1: Demographic distribution of patients and classification of bone - soft tissue defects

\begin{tabular}{|c|c|c|c|c|}
\hline Patient no & Age & Etiology & Fracture & Soft tissue injury \\
\hline 1 & 33 & Explosive & Femur (bilateral) & None \\
\hline 2 & 37 & Explosive & Femur \\
\hline 3 & 26 & Explosive & Femur & None \\
\hline 4 & 37 & Missile & Femur & Skin defect \\
\hline 5 & 28 & Missile & Tibia & Tibia degloving \\
\hline 6 & 23 & Missile & Femur + Tibia & Posterior thigh degloving \\
\hline 7 & 28 & Missile & Tibia+foot+ulna & Skin defects \\
\hline 8 & 21 & Missile & Vertebra & Sciatic nerve \\
\hline 9 & 33 & Explosive & Femur & Popliteral artery \\
\hline 10 & 21 & Missile & Femur (bilateral) & Sciatic nerve \\
\hline 11 & 32 & Explosive & Scapula & Sciatic nerve \\
\hline 12 & 36 & Explosive & Femur & None \\
\hline 13 & 27 & Explosive & None & None \\
\hline 14 & 19 & Explosive & Vertebra & Femoral artery \\
\hline 15 & 34 & Missile & Foot+skull & Femur \\
\hline 16 & 24 & Explosive & &
\end{tabular}




\begin{tabular}{|c|c|c|c|c|}
\hline Patient no & Blood culture & Wound culture & Other cultures & \\
\hline 1 & Acinetobacter $b$. & $\begin{array}{c}\text { Acinetobacter b. } \\
\text { Klebsiella p. }\end{array}$ & & \\
\hline 2 & E.coli & $\begin{array}{c}\text { Acinetobacter b. } \\
\text { E.coli }\end{array}$ & & \\
\hline 3 & Enterobacter c. & Enterobacter c. & & \\
\hline 4 & Klebsiella p. & $\begin{array}{l}\text { Acinetobacter b. } \\
\text { Enterococcus f. } \\
\text { Providencia s. }\end{array}$ & & \\
\hline 5 & None & Stenotrophomonas m & & \\
\hline 6 & Klebsiella p. & $\begin{array}{l}\text { Acinetobacter b. } \\
\text { E.coli } \\
\text { Klebsiella p. }\end{array}$ & & \\
\hline 7 & Acinetobacter $b$. & $\begin{array}{l}\text { Acinetobacter b. } \\
\quad \text { MRCNS } \\
\text { Stenotrophomonas m. }\end{array}$ & & \\
\hline 8 & Acinetobacter $b$. & $\begin{array}{l}\text { Acinetobacter b. } \\
\text { E.coli } \\
\text { Klebsiella p. }\end{array}$ & & \\
\hline 9 & None & None & & \\
\hline 10 & Pseudomonas a. & Klebsiella p. & & \\
\hline 11 & Klebsiella p. & Klebsiella p. & Klebsiella p. & \\
\hline 12 & None & $\begin{array}{c}\text { Candida albicans. } \\
\text { Enterococcus f. } \\
\text { E.coli } \\
\text { Klebsiella p. }\end{array}$ & Enterobacter c. & \\
\hline 13 & None & & Klebsiella p. & \\
\hline 14 & None & & Klebsiella p. & \\
\hline 15 & None & Acinetobacter $b$. & Acinetobacter $b$. & \\
\hline 16 & Pseudomonas a. & Pseudomonas a. & & \\
\hline \multicolumn{5}{|c|}{$\begin{array}{l}\text { Acinetobacter b.: Acinetobacter baumannii, Enterobacter c.: Enterobacter Cloacae, Enterococcus f .. } \\
\text { Enterococcus faecalis, E. coli: Escherichia coli, , Klebsiella p.: Klebsiella pneumoniae, MRCNS: methicillin- } \\
\text { resistant coagulase-negative Streptococcus, Providencia s: Providencia stuartii, Stenotrophomonas m.: Ste- } \\
\text { notrophomonas maltophilia. }\end{array}$} \\
\hline
\end{tabular}

Eight of the patients already had external fixators at admission. One patient had an infected intramedullary nail. In 4 patients the external fixators were removed and internal fixation was performed. Implant infection developed in 2 of these cases. Implants were removed and definitive treatment of these patients was performed with external fixators (Table 3).

Two patients had tympanic membrane rupture due to the shock waves of missile injuries. They were treated in the otolaryngology department. Four patients had lung infections (Table 2, Figure 4). Acinetobacter and Klebsiella were isolated in bronchial lavage cultures. Renal insufficiency and hepatotoxicity developed in 4 patients after colistin administ- ration due to resistant infection. After stopping the colistin, the renal failure and hepatotoxicity regressed (Table 3).

Septic shock and musculoskeletal and soft tissue infections were treated in all surviving patients. Femoral union could not be achieved in 4 patients. In one patient, union was achieved with shortening. All other patients had union in the femur, tibia, ulna, and lumbar spine. At the end of treatment, 2 patients were able to walk without support and 11 patients could walk using support and one patient who was Quadriplegic was unable to walk (Table 3). Two patients died, one had head trauma and abdominal injury and one had head trauma and thorax trauma. 


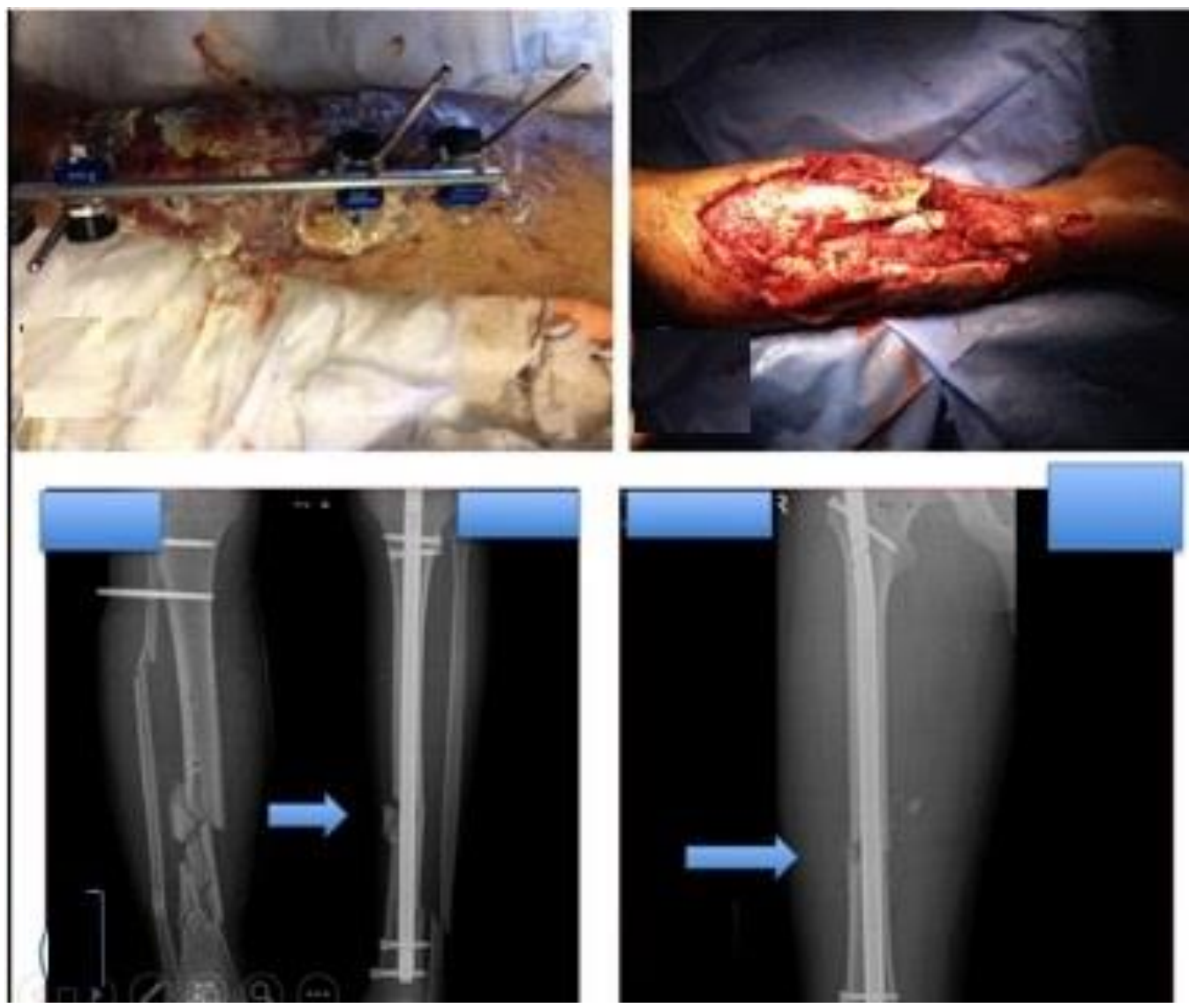

Figure 1: Patient had an infected open fracture and external fixation was performed before transfer. Bone fragments of the tibia following extensive soft tissue debridement. Monolateral external fixator and gastrocnemiussoleus muscle flap were applied. Segmented open fracture of the right and closed fracture of the left tibia.
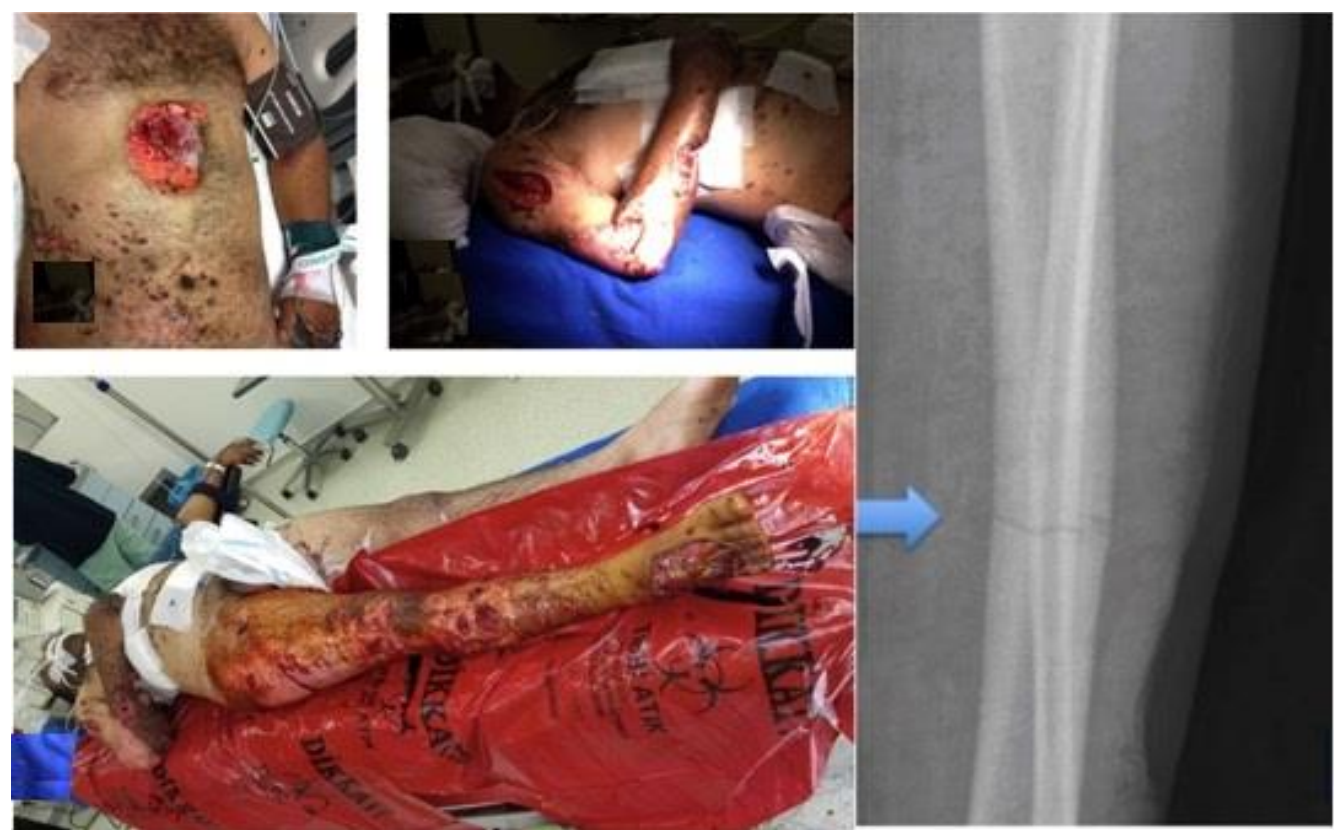

Figure 2: Patient injured by missile attack, with wound on the anterior chest wall caused by shrapnel. Wound on right shoulder and forearm, and open ulna fracture with defect, accompanied by ulnar artery and ulnar nerve injury. Shrapnel was removed from the shoulder. Tissue loss in the lower extremity due to shrapnel and blast effect. Transverse tibia fracture may have been caused by fall or blast effect. 


\begin{tabular}{|c|c|c|c|c|c|c|}
\hline No & Age & Complication & Other & Status & Radiological result & $\begin{array}{c}\text { Clinical } \\
\text { result }\end{array}$ \\
\hline 1 & 33 & $\begin{array}{l}\text { Renal failure due } \\
\text { to colistin }\end{array}$ & $\begin{array}{c}\text { Bilateral sicatic } \\
\text { nervepalsy }+ \text { left } \\
\text { popliteal artery repair }\end{array}$ & Survived & $\begin{array}{l}\text { Right femur healed, } \\
\text { left femur nonunion } \\
\text { without infection }\end{array}$ & $\begin{array}{c}\text { Could walk } \\
\text { with crutches }\end{array}$ \\
\hline 2 & 37 & None & None & Survived & Femur healed & Walk freely \\
\hline 3 & 26 & None & None & Survived & Femur nonunion & $\begin{array}{c}\text { Could walk } \\
\text { with crutches }\end{array}$ \\
\hline 4 & 37 & Thorax injury & None & Survived & $\begin{array}{c}\text { Femur healed with } \\
\text { shortening }\end{array}$ & $\begin{array}{c}\text { Could walk } \\
\text { with crutches }\end{array}$ \\
\hline 5 & 28 & $\begin{array}{l}\text { Renal and hepatic } \\
\text { toxicity of } \\
\text { colistin }\end{array}$ & None & Survived & $\begin{array}{l}\text { Both femur and } \\
\text { tibia healed }\end{array}$ & $\begin{array}{c}\text { Could walk } \\
\text { with crutches }\end{array}$ \\
\hline 6 & 23 & $\begin{array}{c}\text { Pneumonia, } \\
\text { thorax, head and } \\
\text { abdomial injuries } \\
+ \text { sepsis }\end{array}$ & $\begin{array}{l}\text { Confusion at first } \\
\text { admission }\end{array}$ & Exitus & $\mathrm{X}$ & $\mathrm{X}$ \\
\hline 7 & 28 & Pneumonia & None & Survived & $\begin{array}{c}\text { Tibia and ulna } \\
\text { healed }\end{array}$ & Walk freely \\
\hline 8 & 21 & $\begin{array}{l}\text { Hepatoxcititiy } \\
\text { and renal failure } \\
\text { due to colistin }\end{array}$ & $\begin{array}{c}\text { Paraparesis (lomber } \\
\text { vertebra fracture), } \\
\text { secondary sepsis } \\
\text { (VAC) }\end{array}$ & Survived & $\begin{array}{c}\text { Lomber vertebra } \\
\text { and wounds healed }\end{array}$ & $\begin{array}{c}\text { Could walk } \\
\text { with crutches }\end{array}$ \\
\hline 9 & 33 & Cholecystitis & Secondary sepsis & Survived & $\begin{array}{l}\text { Femur healed, } \\
\text { tendon transfer, } \\
\text { cholecystectomy }\end{array}$ & $\begin{array}{c}\text { Could walk } \\
\text { with crutches }\end{array}$ \\
\hline 10 & 21 & $\begin{array}{l}\text { Renal failure due } \\
\text { to colistin }\end{array}$ & $\begin{array}{l}\text { Sepsis at the first } \\
\text { admission }\end{array}$ & Survived & $\begin{array}{l}\text { Below knee } \\
\text { amputation }\end{array}$ & $\begin{array}{l}\text { Could walk } \\
\text { with crutches } \\
\text { and orthesis }\end{array}$ \\
\hline 11 & 32 & Septic shock & $\begin{array}{c}\text { Open abdominal } \\
\text { wound at the first } \\
\text { admission (VAC), } \\
\text { amputation }\end{array}$ & Survived & $\begin{array}{l}\text { Foreign body } \\
\text { excision from } \\
\text { abdomen } \\
\end{array}$ & $\begin{array}{c}\text { Could walk } \\
\text { with crutches } \\
\text { and orthesis }\end{array}$ \\
\hline 12 & 36 & $\begin{array}{c}\text { Retroperitoneal } \\
\text { abses }\end{array}$ & $\begin{array}{c}\text { Colon injury, foreign } \\
\text { body excision from } \\
\text { abdomen }\end{array}$ & Survived & $\begin{array}{l}\text { Femur healed, } \\
\text { colon healed }\end{array}$ & $\begin{array}{c}\text { Could walk } \\
\text { with crutches }\end{array}$ \\
\hline 13 & 27 & $\begin{array}{l}\text { Ureter and colon } \\
\text { injury }\end{array}$ & Colostomy & Survived & Colostomy closed & $\begin{array}{l}\text { Could walk } \\
\text { with ortesis }\end{array}$ \\
\hline 14 & 19 & Quadriplegic & $\begin{array}{l}\text { Sepsis at the first } \\
\text { admission, } \\
\text { tracheostomy }\end{array}$ & Survived & Colostomy closed & Quadriplegic \\
\hline 15 & 34 & $\begin{array}{c}\text { Skull fracture, } \\
\text { hemothorax }\end{array}$ & $\begin{array}{l}\text { Sepsis at the first } \\
\text { admission, amputation }\end{array}$ & Exitus & $\mathrm{X}$ & $\mathrm{X}$ \\
\hline 16 & 25 & $\begin{array}{c}\text { Femoral artery } \\
\text { graft }\end{array}$ & Graft infection & Survived & $\begin{array}{l}\text { Graft excised, } \\
\text { collateral } \\
\text { circulation } \\
\end{array}$ & $\begin{array}{l}\text { Could walk } \\
\text { with ortesis }\end{array}$ \\
\hline
\end{tabular}




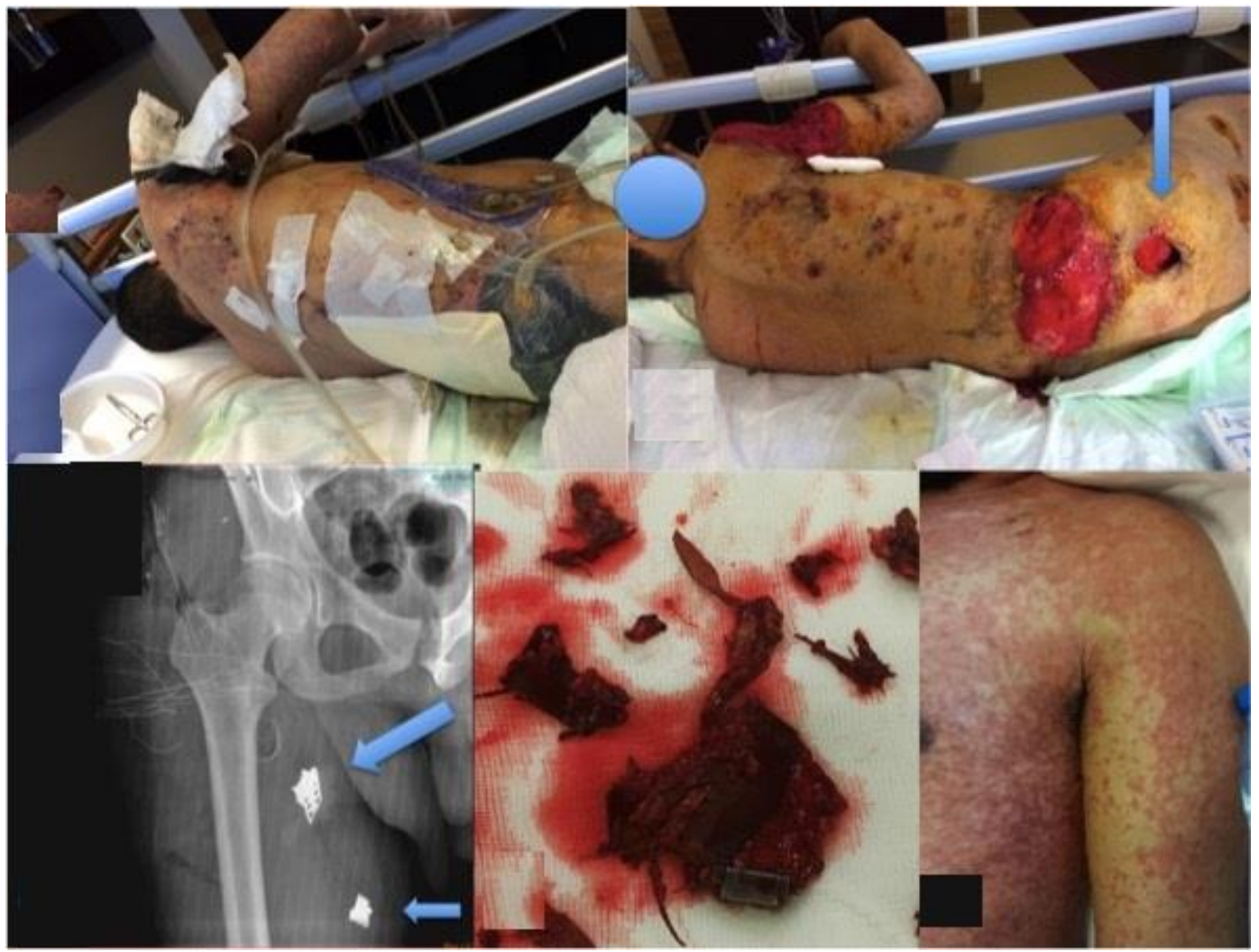

Figure 3: Large soft tissue defect treated with VAC. Healing and regression of skin defect. Metallic foreign bodies in the right hip upon X-ray. Foreign bodies were removed during surgical debridement, including both metal and wooden parts. Toxic shock syndrome with skin rashes before foreign bodies were removed.

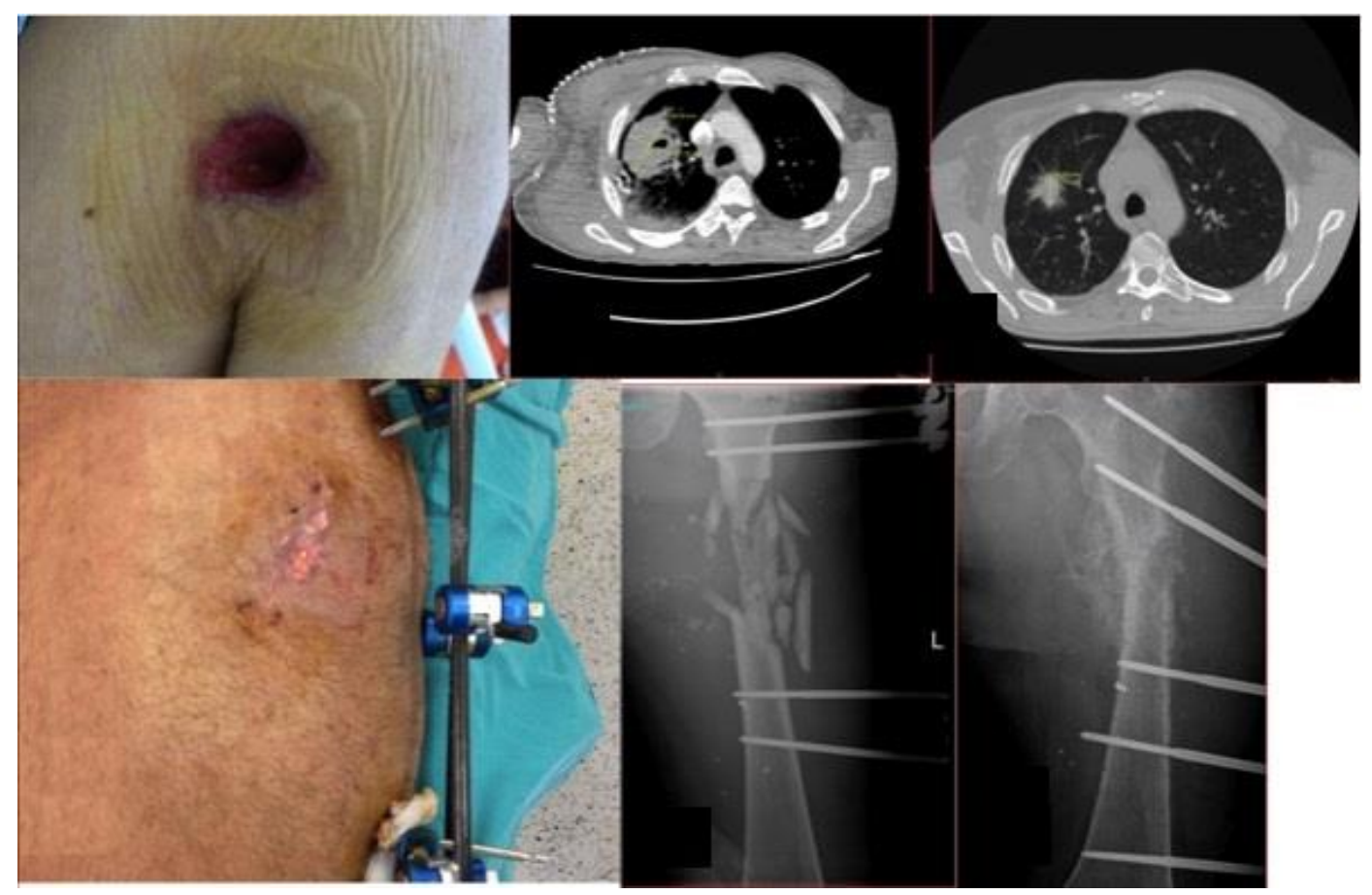

Figure 4: Skin defect with shrapnel fragment regressed with VAC treatment on the posterior side of the right shoulder. Lung injury and pneumonia before treatment. Regression of pneumonia after treatment. Purulent drainage from the left thigh. Bone fragments before debridement. Regression of infection and healing of femur with shortening after debridement. 


\section{DISCUSSION}

Due to ongoing warfare, unfortunately many people continue to be injured and die. The majority of these patients are young. Since some of these patients are injured by high-energy firearms (missiles, explosives etc.), they may also have shock-related injuries. Orthopedic injuries in these patients are highly complex and susceptible to infections. They should be considered as polytrauma patients because of having not only extremity injuries but also other systemic organ injuries. Infections after contamination on the battlefield or in the hospital can cause sepsis and death $(12,13)$. War injuries should be considered as systemic injuries rather than isolated injuries and their treatment should be performed multidisciplinarily, not by a single clinic (8).

In the treatment of war injuries, due to the presence of polytrauma and poor general condition, the first step upon admission of the patient to the hospital is stabilizing the general status. Antibiotherapies are begun at this stage. Patients with critical vital signs are generally directed to intensive care units. Emergency operations such as those for penetrating organ injuries and intracranial injuries are organized immediately. Treatment of limb injuries is recommended to be conducted as damage-control surgery (11). Until the patient's general condition and vital signs are stable, bone fixations (especially of the femur) are done with a temporary external fixator, and then internal fixations and other reconstructive procedures are performed (14). Although there has been significant progress in the treatment of war injuries compared to earlier years, complications due to infection are still the most important cause of mortality and morbidity in both the short and the long term (2). The most effective approach to preventing the infection of war injuries includes early wound debridement, antibiotics, bone stabilization, and infection control.

Data on war injuries are mainly presented by US-based publications and focus on professional military personnel (4). The United States and European countries, starting from the first intervention in the field, can perform transport, first surgical interventions, and then definitive procedures and treatments of their injured military personnel under better conditions. This leads to better outcomes $(3,15)$. On the other hand, in studies of the Sudanese and Syrian civil wars, infection, morbidity, and mortality rates are seen to be higher. Rapid medical transfer/evacuation and surgical treatment of wounded personnel have a significant impact on mortality and morbidity (4). The first interventions of the patients in our study were carried out in the war zone and the details were uncertain (e.g., hospital conditions or first aid tent on site). Patients came to our clinic after an average of 11.37 days from their injuries. Debridement and external fixator treatments were performed in Tunisian hospitals, but transport was carried out by non-professional means and by airways upon infection and deterioration of the general condition of the patients.

When our patients presented to our clinic, 8 of them had previously placed external fixators. In two cases, no fixation had been performed. We removed the fixators of the patients with external fixators and replaced them with new external fixators after debridement. We then performed internal fixation for 4 of the patients. However, for 2 of our patients, we removed the implants due to infection again and switched to external fixators. Despite adequate debridement and normalization of infection parameters, the cases of re-infection in these patients may be explained by the continuation of immunosuppression due to their general conditions and the resistance of existing infectious agents. In previous studies, $16 \%$ of the patients with war injuries developed chronic infections, and between $2 \%$ and $4 \%$ of these cases unfortunately ended in sepsis and death $(12,16)$. In our study, 2 of 16 patients died.

If there is no immune deficiency in young adults, subsequent sepsis after open extremity injury is a rare condition. However, sepsis may develop due to secondary immunosuppression in patients due to other systemic injuries (i.e., polytrauma) $(10,11)$. Serious soft tissue damage, inadequate debridement, inappropriate hospital conditions, inappropriate use of antibiotics, and poor follow-up of patients due to warfare conditions may cause local infections to become chronic and systemic and may even cause sepsis $(2,17)$. In another study, although Staphylococcus aureus was the main infective agent in post-traumatic osteomyelitis, it was also reported that gram-negative enterobacteria had increased in prevalence (13). Studies on battlefield injuries have also reported infections with resistant gramnegative bacteria such as Acinetobacter (18). Staphylococcus aureus-weighted mixed infections have been reported in previous studies on war injuries. Especially in patients exposed to contamination in desert areas, a significant increase in Acinetobacter contamination is observed $(12,19)$. In recent studies, it was reported that inadequate surgical debridement and inappropriate antibiotic administration in field hospitals during and after the first intervention in a desert region led to the development of resistant gram-negative and methicillinresistant Staphylococcus aureus in the late period (20). Except 3 patients mixed infection was observed in all cultures from our patients (Table 2). Acinetobacter baumannii was isolated from the blood of 3 patients, from limb regions in 5 patients, and from the bronchial lavage of 2 patients. These results were consistent with other publications related to the Libyan civil war (21). Multidrug-resistant infections are generally expected to occur in patients staying in long-term hospital intensive care settings and receiving long-term antibiotic treatment (22). However, it was also reported that even in normal flora, multidrug-resistant bacterial colonization is present and resistant infections have begun even in patients with new antibiotic therapy. The reason for this is that there was no control over the use of antibiotics in 
the relevant country before the war $(12,13)$. A similar situation was probably present in Libya.

Colistin was started in 8 of our patients because of severe resistance and failure to control infection. However, 4 patients developed renal failure secondary to colistin. One of these patients died. After renal failure, dose adjustment was performed and then colistin was discontinued. Afterwards, renal failure improved in the other patients and their infections were controlled. The antibiotics administered to multidrug-resistant patients are recommended to be used with close monitoring due to their toxicity (16).

Another important point in patients with polytrauma and injuries of the extremities is soft tissue injury and loss of skin integrity. Five of our patients had severe skin loss and associated soft tissue infection. These patients were treated with serial debridement and VAC. Treatment with VAC facilitates the soft tissue treatment of such patients considerably (23). It is especially recommended for war injuries in current treatment approaches (24). However, because VAC treatment is a closed system treatment, it is likely to prepare the grounds for anaerobic bacteria (25). In our patient group, the patient who died had also received VAC treatment. In addition, toxic shock syndrome occurred in one patient due to the application of VAC with a foreign body in the soft tissue during the treatment of skin necrosis after discharge from sepsis (Figure 3). He had superficial cellulite-like rashes before the onset of toxic shock. This patient previously had Acinetobacter growth in blood culture. Acinetobacter baumannii, Klebsiella pneumoniae, and E. coli mixed growth was also seen in the wound culture of this patient. Toxic shock syndrome following cellulitis is a condition that can occur in cases of Acinetobacter and associated bacteria and can be overlooked (19). Thereafter, VAC treatment was terminated and the foreign body in the soft tissue was removed. The treatment of the patient continued with a series of debridements and intravenous antibiotherapy.

In high-energy ballistic injuries, problems can be seen not only in the directly injured area but also in indirectly affected areas (10). Especially in wounds such as those from missiles that generate serious pressure waves, tympanic membrane injuries, alveolar damage, long bone diaphysis injuries, and bladder rupture can be seen (26). Two patients had tympanic membrane injury and two had transverse, closed long bone diaphyseal injuries of the other extremities. In one of our patients, we attributed the occurrence of lung problems to alveolar damage very early.

In summary, war injuries caused by highenergy weapons are complex injuries and cause high mortality and morbidity in patients. In general, the first intervention for these injuries is usually performed under war conditions and unfortunately is insufficient (17). When other accompanying systemic injuries are added, local infections cause sepsis. Bacteria that can be isolated in these patients are generally resistant microorganisms and antibiotics with high toxicity may be used in their treatment. This is a serious cause of morbidity and even mortality. Bone infection treatments are also more difficult than in other patient groups. Finally, the shock effects of some high-energy weapons can be significant. This may lead to other secondary organ injuries.

\section{Conclusion}

Our study supports the literature with a multidisciplinary and successful approach to war injuries, and with similar findings and treatment of multidrugresistant infections. War injuries are different from other type of injuries. Just focusing only on bone and soft tissue damage in wounded sides may draw us leave out other injuries. We tried to draw attention to the injuries caused by blast effect (alveolar damage, diaphyseal stress fractures of long bones, tympanic membrane injuries) in our study. However, we had an important complication that is rarely seen in VAC treatment. Although VAC is helpful in the treatment of open and complex wounds, we think that anaerobic bacterial colonization and septic complications of VAC should be kept in mind in cases of war injuries.

The limitations of our study are its retrospective nature, the small number of patients, and the shortto-medium follow-up period. Our study reports good outcomes, but we could not perform long-term followup of the patients as all of the patients returned to their home countries. It is also quite difficult to plan a prospective study for war injuries due to the multicenter and long-lasting treatments.

\section{Conflict of interest and disclosure}

The authors received no financial support for the research.

The authors declare that they have no competing interests

\section{REFERENCES}

1. Hakimoğlu S, Karcioğlu M, Tuzcu K, et al. Assessment of the perioperative period in civilians injured in the Syrian Civil War. Braz J Anesthesiol. 2015; $65: 445-49$

2. Murray CK. Epidemiology of infections associated with combat-related injuries in Iraq and Afghanistan. J Trauma. 2008;64:232-8.

3. Olson CM Jr, Bailey J, Mabry R, Rush S, Morrison JJ, Kuncir EJ. Forward aeromedical evacuation: a brief history, lessons learned from the Global War on Terror, and the way forward for US policy. J Trauma Acute Care Surg. 2013;75:130-6.

4. Blyth DM, Yun HC, Tribble DR, Murray CK. Lessons of war: Combat-related injury infections during the Vietnam War and Operation Iraqi and Enduring Freedom. J Trauma Acute Care Surg. 2015;79:22735 .

5. Murray CK, Hsu JR, Solomkin JS, et al. Prevention and management of infections associated with combat-related extremity injuries. J Trauma. 2008;64: 239-51.

6. Scott SG, Belanger HG, Vanderploeg RD, Massengale J, Scholten J. Mechanism-of-injury approach to 
evaluating patients with blast-related polytrauma. J Am Osteopath Assoc. 2006;106:265-70.

7. Doucet JJ, Galarneau MR, Potenza BM, et al. Combat versus civilian open tibia fractures: the effect of blast mechanism on limb salvage. J Trauma. 2011; 70:1241-7.

8. Lohr B, Pfeifer Y, Heudorf U, Rangger C, Norris DE, Hunfeld KP. High Prevalence of MultidrugResistant Bacteria in Libyan War Casualties Admitted to a Tertiary Care Hospital, Germany. Microb Drug Resist. 2018;24:578-84.

9. Ng C, Mifsud M, Borg JN, Mizzi C. The Libyan civil conflict: selected case series of orthopaedic trauma managed in Malta in 2014. Scand J Trauma Resusc Emerg Med. 2015;23:103.

10. Ma XY, Tian LX, Liang HP. Early prevention of trauma-related infection/sepsis. Mil Med Res. 2016; $3: 33$.

11. McKinley TO, Gaski GE, Vodovotz Y, Corona BT, Billiar TR. Diagnosis and management of polytraumatized patients with severe extremity trauma. J Orthop Trauma. 2018;32 Suppl 1:S1-S6.

12. Älgå $\mathrm{A}$, Wong $\mathrm{S}$, Shoaib $\mathrm{M}$, et al. Infection with high proportion of multidrug-resistant bacteria in conflict-related injuries is associated with poor outcomes and excess resource consumption: a cohort study of Syrian patients treated in Jordan. BMC Infect Dis. 2018;18:233.

13. Fily F, Ronat JB, Malou N, et al. Post-traumatic osteomyelitis in Middle East war-wounded civilians: resistance to first-line antibiotics in selected bacteria over the decade 2006-2016. BMC Infect Dis. 2019;19:103.

14. O'Toole RV, O'Brien M, Scalea TM, Habashi N, Pollak AN, Turen CH. Resuscitation before stabilization of femoral fractures limits acute respiratory distress syndrome in patients with multiple traumatic injuries despite low use of damage control orthopedics. J Trauma. 2009;67:1013-21.

15. Lloyd BA, Murray CK, Shaikh F, et al. Early infectious outcomes after addition of fluoroquinolone or aminoglycoside to posttrauma antibiotic prophylaxis in combat-related open fracture injuries. J Trauma Acute Care Surg. 2017;83:854-61.

16. Murray CK. Infectious disease complications of combat-related injuries. Crit Care Med. 2008;36: 358-64.

17. Clasper JC, Rowley DI. Outcome, following significant delays in initial surgery, of ballistic femoral fractures managed without internal or external fixation. J Bone Joint Surg Br. 2009;91:97-101.

18. Dau AA, Tloba S, Daw MA. Characterization of wound infections among patients injured during the 2011 Libyan conflict. East Mediterr Health J 2013; 19:356-61.

19. Sebeny PJ, Riddle MS, Petersen K. Acinetobacter baumannii skin and soft-tissue infection associated with war trauma. Clin Infect Dis. 2008;47:444-9.
20. Yun HC, Branstetter JG, Murray CK. Osteomyelitis in military personnel wounded in Iraq and Afghanistan. J Trauma. 2008;64:S163-8.

21. Dau AA, Tloba S, Daw MA. Characterization of wound infections among patients injured during the 2011 Libyan conflict. East Mediterr Health J. 2013;19:356-61.

22. Campbell WR, Li P, Whitman TJ, et al. Multi-DrugResistant Gram-Negative Infections in DeploymentRelated Trauma Patients. Surg Infect (Larchmt). 2017;18:357-67.

23. Hinck D, Franke A, Gatzka F. Use of vacuumassisted closure negative pressure wound therapy in combat-related injuries--literature review. Mil Med. 2010;175:173-81.

24. Leininger BE, Rasmussen TE, Smith DL, Jenkins $\mathrm{DH}$, Coppola C. Experience with wound VAC and delayed primary closure of contaminated soft tissue injuries in Iraq. J Trauma. 2006;61:1207-11.

25. Gwan-Nulla DN, Casal RS. Toxic shock syndrome associated with the use of the vacuum-assisted closure device. Ann Plast Surg. 2001;47:552-4.

26. Kieser DC, Carr DJ, Leclair SC, et al. Gunshot induced indirect femoral fracture: mechanism of injury and fracture morphology. J R Army Med Corps. 2013;159:294-9. 